quantity of either of these substances, placed in a bulb a cubic inch in volume, warmed, and exposed to the intermittent beam, emits a sound of extraordinary power.

I also tried to extract sounds from perfumes, which $I$ had proved in $186 \mathrm{r}$ to be absorbers of radiant heat. I limit myself here to the vapours of pachouli and cassia, the former exercising a measured absorption of 30 , and the latter an absorption of rog. Placed in dried flasks, and slightly warioed, sounds were obtained from both these substances, but the sound of cassia was much louder than that of pachouli.

Many years ago I had proved tetrachloride of carbon to be highly diathermanou: Its sounding power is as feeble as its absorbent power.

In relation to colliery explissions, the deportment of marsh-gas was of special interest. Prof. Dewar was good enough to furnish me with a pure sample of this gas. The sounds produced by it, when exposed to the intermittent beam, were very powerful.

Chloride of methyl, a liquid which boils at the ordinary tem. perature of the air, was poured into a small flask, and permitted to displace the air within it. Exposed to the intermittent beam, its sound was similar in power to that of marsh-gas.

The specific gravity of marsh-gas being about half that of air, it might be expected that the flask containing it, when left open and erect, would soon get rid of its contents. This however is not the case. After a considerable interval the film of this gas clinging to the interior surface of the flask was able to produce sounds of great power.

A small quantity of liquid bromine being poured into a welldried flask, the brown vapour rapidly diffused itself in the air above the liquid. Placed in the intermittent beam, a somewhat forcible sound was produced. This might seem to militate against my former experiments, which assigned a very low absorptive power to bromine vapour. But my former experiments on this vapour were conducted with obscure heat; whereas in the present instance $\mathrm{I}$ had to deal with the radiation from incandescent lime, whose heat is in part luminous. Now the colour of the bromine vapour proves it to be an energetic absorber of the luminous rays; and to them, when suddenly converted into thermometric heat in the body of the vapour, I thought the sounds might be due.

Between the flask containing the bromine and the rotating disk I therefore placed an empty glass cell : the sounds continued. I then filled the cell with transparent bisulphide of carbon : the sounds still continued. For the transparent bisulphide I then substituted the same liquid saturated with dissolved iodine. This solution cut off the light, while allowing the rays of heat free transmission: the sounds were immediately stilled.

Iodine vaporised by heat in a small flask yielded a forcible sound, which was not sensibly affected by the interposition of transparent bisulphide of carbon, but which was completely quelled by the iodine solution. It might indeed have been foreseen that the rays transmitted by the iodine as a liquid would also be transmitted by its vapour, and thus fail to be converted into sound. ${ }^{1}$

To complete the argument:-While the flask containing the bromine vapour was sounding in the intermictent beam, a strong solution of alum was interposed between it and the rotating disk. There was no sensible abatement of the sounds with either bromine or iodine vapour.

In these experiments the rays from the lime-light were converged to a point a little beyond the rotating disk. In the next experiment they were rendered parallel by the mirror, and afterwards rendered convergent by a lens of ice. At the focus of the ice-lens the sounds were extracted from both bromine and iodine vapour. Sounds were also produced after the beam had been sent through the alum solution and the ice-lens conjointly.

With a very rude arrangement I have been able to hear the sounds of the more active vapours at a distance of 100 feet from the source of rays.

Several vapours other than those mentioned in this abstract have been examined, and sounds obtained from all of them The vapours of all compound liquids will, I doubt not, be found sonorous in the intermittent beam. And, as I question whethe there is an absolutely diathermanous substance in nature, I think it probable that even the vapours of elementary bodies, including the elementary gases, when more strictly examined, will be found capable of producing sounds.

$$
{ }^{x} \text { I interitionally use this phraseology. }
$$

\section{INTERESTING NEW CRINOIDS}

$\mathrm{IN}$ the Memoirs of the Swiss Palæontological Society for $\mathrm{I} 880$ Prof. P. de Loriol has recently described a remarkable new Crinoid which he refers to the little known genus Thiolliericrinus, Étallon, under the name of $T$. ribeiroi. It occurs in the Upper Jurassic beds of Engenheiro, in Portugal. The calyx, like that of most Jurassic Comatule, has five small prismatic basals attached to the under surface of the radials. But the centrodorsal piece on which the calyx rests is not entirely separated fro:n the lower part of the stem, as is the case in the Comatula, though it resembles that of a Comatula in bearing cirrhi.

Thiolliericrinus was a stalked Crinoid that never developed beyond the stage at which cirrhi appear on the enlarged uppermost stem-joint of the stalked larva of Comatula. The underface of the centrodorsal and the terminal faces of the other stem-joints resemble those of the Comatula larva and also of Bourgueticrinus and Rhizocrinus in their oval shape and in the presence of transverse ridges which are in different planes at the two ends of each joint. Thiolliericrinus therefore is a permanent larval form, and furnishes an intermediate stage between the stalked Bourgueticrinus and the free Comatula. The top stemjoint of the former bears no cirrhi, as it does in Thiolliericrinus and in Comatula; while in the latter it develops cirrhi, and unites closely with the calyx, separating from the rest of the larval stem on which it was previously fixed.

Another form of considerable morphological interest, from its occupying an intermediate position between two well-defined genera, has been lately described by Mr. P. H. Carpenter under the name of Mesocrinus. The stem-joints are of the type already mentioned as characteristic of Bourguticrinus, having oval faces marked by transverse ridges in different planes. But the upper stem-joint is not enlarged as it is in Bourgueticrinus and in the Apiocrinide generally, while the form of the calyx recalls that of the Pentacrinida. It consists of five radials with well-developed articular faces, resting on five basals which form a complete ring as in the recent Pentacrinus Wyville-Thomsoni, from 800 fathoms in the Atlantic off the coast of Portugal.

Broadly speaking, therefore, Mesocrinus combines the stem of Bourgueticrinus with the calyx of Pentacrinus, or rather of Cainocrinus, as Prof. de Loriol prefers to call that section of the Pentacrimus type in which the basal ring is closed. Mesocrinus is an Upper Cretaceous genus, one species occurring in the "Plänerkalk" of Streben in Saxony, while another and larger one was found in the "Mucronaten Kreide" of Southern Sweden.

\section{UNIVERSITY AND EDUCATIONAL INTELLIGENCE}

OXFORD.-In consequence of the unsatisfactory state of many of the lodging-houses in Oxford, in respect of their sanitary arrangements, a proposal will be brought before Congregation on March I " to make better provision for the supervision of lodging-houses." One of the delegates for licensing lodgings will be stipendiary, and it will be his duty to inspect every dwelling-house proposed for this use and to satisfy himself of its sanitary fitness. He shall have the assistance of a sanitary inspector, and shall have proctorial authority over members of the University in his character of inspector.

A special statute will also be proposed authorising the present delegates of lodging-houses to spend whatever sum they may think necessary on a general inspection of lodging-houses during the present year.

There will be holden at Christ Church on Saturday, March 12, an election to at least one Mathematical Junior Studentship, and at least one in Natural Science, tenable for five years from the day of election. They will be of the annual value either $(\mathbf{r}$ of $100 \%$. (including an allowance for room rent) if the Governing Body shall so determine; or (2) of 85 . (also including an allowance for room rent), which may be raised to the larger sum above named after the completion of one year's residence, if the Governing Body shall so determine. Candidates for the Mathematical Studentships and candidates for the Natural Science Studentships who offer mathematics will call upon the Dean on Monday, Febrwary 28, between 12.30 and 1.30 p.m.; candidates for the Natural Science Studentships who do not offer mathematics, on March 2, between 12.30 and I.30 p.m. Al must produce certificates both of the day of their birth and of good character. The examinations will follow in each case at 